JKEP

Vol 5, No 2, November 2020

ISSN: 2354-6042 (Print)

ISSN : 2354-6050 (Online)

\title{
Hubungan Motivasi Dengan Perawatan Diri Pasien Hipertensi
}

\author{
Akhmad Naufal Su'ud, Murtaqib, Kushariyadi \\ Universitas Jember \\ email: naufalsuud991@gmail.com
}

\author{
Artikel history \\ Dikirim, Mar $20^{\text {th }}, 2020$ \\ Ditinjau, Nov $25^{\text {th }}, 2020$ \\ Diterima, Nov $28^{\text {th }}, 2020$
}

\begin{abstract}
The risk of complications in patients with hypertension can be prevented by good self-care behaviour. Self-care is the main factor that can be done to control blood pressure. Motivation is one of the determining factors for someone to do something they want. This study aims to analyze the correlation between motivation and self-care of hypertensive patients. A total of 84 respondents were selected in the study by using consecutive sampling techniques. Data was collected by distributing questionaires of Hypertension Self Care Profile (HBP-SCP) behaviour scale and Motivation Scale. Data were analyzed by using Spearman correlation test with a significance value of 0.05. The results showed that mean of motivation and self-care was 59,92 and 56,43. There was significant positive correlation between the two variables ( $p$-value:0,000 $r:+0,444)$. This result means that the higher the motivation of a person, the higher the self-care behavior. Based on these results, the authors suggest increasing patient motivation in order to improve self-care behavior of hypertensive patients independently.
\end{abstract}

Keywords: Hypertension; Motivation; Self Care Hypertension

\begin{abstract}
ABSTRAK
Resiko terjadinya komplikasi pada penderita hipertensi dapat dicegah dengan melakukan perilaku perawatan diri yang baik. Perawatan diri merupakan faktor utama yang dapat dilakukan untuk mengendalikan tekanan darah. Motivasi merupakan salah satu faktor penentu seseorang untuk melakukan sesuatu yang dikehendaki. Penelitian ini bertujuan untuk menganalisis hubungan antara motivasi dengan perawatan diri pasien hipertensi. Sebanyak 84 responden dipilih dalam penelitian menggunakan teknik consecutive sampling. Pengambilan data dilakukan dengan membagikan kuesioner Hypertension Self Care Profile (HBP-SCP) Behaviour Sacle dan Motivation Scale. Analisis data menggunakan uji korelasi spearman dengan nilai signifikansi 0,05 . Hasil penelitian menunjukkan bahwa nilai rata-rata motivasi dan perawatan diri dari masingmasing adalah 59,92 dan 56,43. Terdapat hubungan signifikan antara kedua variabel dan bersifat positif ( $p$ value: $0,000 \mathrm{r}:+0,444$ ). Hasil ini memiliki makna bahwa semakin tinggi motivasi seseorang maka semakin tinggi juga perilaku perawatan diri. Berdasarkan hasil tersebut maka penulis menyarankan untuk meningkatkan motivasi pasien supaya dapat meningkatkan perilaku perawatan diri pasien hipertensi secara mandiri.
\end{abstract}

Kata Kunci: Hipertensi; Motivasi; Perawatan Diri Hipertensi 


\section{PENDAHULUAN}

Perawatan diri merupakan faktor utama yang dapat dilakukan untuk mengendalikan tekanan darah (Motlagh dkk., 2016). Gaya hidup serta tingkat kesadaran yang rendah juga dapat menjadi faktor resiko terjadinya hipertensi dalam masyarakat (Indrayanti dkk., 2018). Hal ini didukung oleh penelitian dari Siregar (2019) yang menyatakan perawatan diri kurang dan gaya hidup masyarakat yang tidak sehat seperti mengkonsumsi sayur dan serat yang kurang, terlalu banyak mengkosumsi makanan siap saji, garam, makanan yang berlemak, dan gula yang terus meningkat menjadi penyebab tingginya angka kejadian hipertensi di masyarakat.

\section{Menurut World Health Organisation} (WHO), penyakit tidak menular (PTM) seperti penyakit jantung, kanker, stroke, penyakit obstruksi kronik, diabetes melitus, dan hipertensi menjadi penyebab kematian sebanyak 36 juta jiwa per tahun di seluruh dunia (63\%). Secara keseluruhan pravelensi penderita hipertensi di Indonesia pada tahun 2018 mencapai angka rata-rata $34,1 \%$ (Riskesdas, 2018). Hipertensi menyebabkan kematian sekitar 7 juta penduduk di Indonesia (Rohman dkk., 2011). Berdasarkan data Dinas Kesehatan Provinsi Jawa Timur (2018) menunjukkan bahwa total penderita hipertensi sebanyak
1.828.669 penduduk, dengan proporsi jumah penderita laki-laki sebesar 825.412 penduduk, dan penderita hipertensi pada perempuan sebesar 1.003.257 penduduk. Menurut data Dinas Kesehatan Kabupaten Jember (2016) hipertensi menempati posisi ke-2 setelah penyakit infeksi akut sebagai 10 besar penyakit di Kabupaten Jember dengan total 59,736 orang

Penelitian yang dilakukan oleh Ademe (2019) di Ethiopia tentang perawatan diri penderta hipertensi pada 309 pasien menunjukkan bahwa rata-rata pasien hipertensi memiliki perawatan diri yang buruk. Hasil penelitian yang sama juga didapatkan oleh Karmacharya (2017) yang dilakukan pada pasien hipertensi di Nepal menunjukkan $(52 \%)$ responden memiliki praktik perawatan diri yang kurang. Di Indonesia sendiri penelitian yang dilakukan oleh Cahyani (2019) pada 40 pasien hipertensi didapatkan sebanyak $(27,1 \%)$ pasien memiliki perawatan diri yang kurang. Karena disebut sebagai silent killer penderita hipertensi cederung kurang menyadari pentingnya perawatan diri hipertensi (Dasgupta dkk., 2018).

Perawatan diri seseorang dapat dipengaruhi oleh beberapa faktor diantaranya keyakinan, motivasi pasien, harapan, pengetahuan, dan 
dukungan baik dari keluarga maupun petugas kesehatan (Kharisna dkk., 2017). Motivasi merupakan salah satu faktor penentu seseorang untuk melakukan sesuatu yang dikehendaki (Purdiyanti, 2019). Sementara dalam penelitian yang dilakukan oleh Lestari (2018) pada 36 responden dengan hipertensi didapatkan hanya 30\% pasien yang melakukan perubahan gaya hidup.

Motivasi pasien menjadi hal yang penting untuk dimiliki pasien dalam meningkatkan perawatan diri guna meningkatkan kesembuhan penderita hipertensi (Schumacher \& Jacksonville, 2005 dalam Damawiyah, 2017). Motivasi merupakan sesuatu yang mendorong atau bertindak sebagai pendorong bagi seseorang untuk melakukan tingkah laku untuk mencapai tujuan (Saam, 2012 dalam Dani dkk., 2015). Tujuan dalam penelitian ini adalah untuk menganalisis hubungan motivasi pasien dengan perawatan diri pasien hipertensi. Di masa depan diharapkan perawat dapat memberikan perhatian terhadap peningkatan motivasi agar terjadi peningkatan perawatan diri yang dilakukan oleh pasien.

\section{METODE}

Penelitian ini menggunakan desain penelitian observasional analitik dengan pendekatan cross sectional. Populasi dalam penelitian ini adalah seluruh pasien hipertensi di poli klinik Rumah Sakit Tingkat III Balladhika Husada Jember. Sampel pada penelitian ini adalah pasien hipertensi yang memenuhi kriteria inklusi diantaranya a) tekanan darah sistolik $\geq 140 \mathrm{mmhg}$ dan diastolik $\geq 90$ mmhg b) berusia 18-85 tahun c) responden usia $>60$ tahun lolos tes mini mental state examination d) dapat berkomunikasi dengan baik, dan kriteria eksklusi diantaranya a) memiliki gangguan fisik berat b)memiliki keterbatasan fisik seperti buta dan tuli. Teknik sampling yang digunakan dalam penelitian ini adalah nonprobability sampling dengan cara consecutive sampling. Penentuan sampel menggunakan $G$ Power dan didapatkan sejumlah 84 responden.

Kuesioner demografi digunakan untuk menganalisa karakteristik responden diantaranya jenis kelamin, pekerjaan, riwayat pendidikan, usia, riwayat hipertensi. kuesioner Hypertension self-care Profile (HBP SCP) behavior scale digunakan untuk mengukur perawatan diri pasien hipertensi. Kuesioner ini terdiri dari 20 pertanyaan dengan skala likert dengan skor terendah 20 dan tertinggi adalah 80. Kuesioner hypertension self-care Profile (HBP SCP) motivation scale digunakan untuk mengukur motivasi. Kuesioner ini terdiri dari 20 pertanyaan dengan skala likert dengan nilai terendah 20 dan tertinggi 80 . 
Penelitian ini menggunakan analisa univariat dan bivariat, analisa univariat dalam penelitian ni termasuk didalamnya karakteristik responden, sementara analisa bivariat penelitian ini menggunakan spearman rank. Dengan nilai signifikansi yang digunakan adalah $\mathrm{p}<0,05$. Penelitian ini telah memenuhi kriteria uji etik penelitian di Fakultas Kedokteran Gigi Universitas Jember No.725/UN25.8/KEPK/DL/2019.

\section{HASIL DAN PEMBAHASAN}

Tabel 1. Distribusi data karakteristik responden $(n=84)$

\begin{tabular}{|c|c|c|}
\hline Variabel & Mean & Min-Max \\
\hline Usia & 59,61 & $27-83$ \\
\hline Variabel & $\begin{array}{l}\text { Jumlah } \\
\text { (f) }\end{array}$ & $\begin{array}{l}\text { Presentase } \\
(\%)\end{array}$ \\
\hline \multicolumn{3}{|l|}{ Jenis Kelamin } \\
\hline Laki-laki & 31 & 36,9 \\
\hline Perempuan & 53 & 63,1 \\
\hline \multicolumn{3}{|l|}{ Riwayat Hipertensi } \\
\hline Memiliki Riwayat Hipertensi & 66 & 78,6 \\
\hline Tidak Memiliki Riwayat Hipertensi & 18 & 21,4 \\
\hline \multicolumn{3}{|l|}{ Riwayat Pendidikan } \\
\hline Tidak Sekolah & 8 & 9,5 \\
\hline SD & 25 & 29,8 \\
\hline SMP & 21 & 25,0 \\
\hline SMA & 17 & 20,2 \\
\hline Perguruan Tinggi & 13 & 15,5 \\
\hline \multicolumn{3}{|l|}{ Pekerjaan } \\
\hline Tidak Bekerja & 34 & 40,5 \\
\hline Ibu Rumah Tangga & 27 & 32,0 \\
\hline PNS & 5 & 6,0 \\
\hline Wiraswasta & 13 & 15,5 \\
\hline Lain-Lain & 5 & 6,0 \\
\hline
\end{tabular}

Berdasarkan data distribusi karakteristik responden pada tabel $1 \mathrm{di}$ atas, terlihat bahwa usia responden dimana rata-rata usia responden hipertensi di Poli Klinik Rumah Sakit Tingkat III Baladhika Husada Jember adalah 59,61 tahun. Rentang usia termuda adalah 27 tahun dan usia tertua adalah 83 tahun. Jumlah responden dengan jenis kelamin perempuan lebih banyak dengan jumlah 53 orang $(63,1 \%)$. Sedangkan untuk riwayat hipertensi rata-rata responden dengan memiliki riwayat hipertensi dalam keluarga memiliki jumlah yang lebih banyak dengan total 66 orang $(77,8 \%)$. Sementara riwayat pendidikan didominasi oleh orang dengan riwayat pendidikan SD dengan jumlah 25 orang (29,8\%). Adapun untuk pekerjaan paling banyak didominasi oleh responden yang tidak bekerja dengan jumlah 34 orang $(40,5 \%)$. 
Tabel 2. Nilai rerata motivasi pasien hipertensi $(n=84)$

\begin{tabular}{llll}
\hline Variabel & Mean & SD & Min-Max \\
\hline Motivasi & 59,92 & 3,847 & $50-69$ \\
\hline
\end{tabular}

Pada tabel 2 menunjukkan bahwa nilai ratarata motivasi pasien adalah 59,92 dengan standar deviasi 3,847. Penelitian ini memiliki hasil yang sama dengan penelitian yang dilakukan oleh Wulandhani dkk. (2014) tentang motivasi pasien untuk melakukan diet hipertensi didapatkan hasil bahwa dari total 91 responden sebanyak $53,8 \%$ responden memiliki motivasi yang baik. Penelitian lain yang memiliki hasil serupa dilakukan oleh Fitriana dkk. (2014) tentang motivasi dalam menjalani pengobatan hipertensi didapatkan hasil bahwa dari total 110 responden penelitiannya diketahui sebanyak 92,7\% responden memiliki motivasi baik. Penelitian ini juga didukung penelitian yang dilakukan oleh Jati (2012) Motivasi pasien hipertensi didapatkan hasil bahwa sebanyak $26,8 \%$ responden memiliki motivasi tinggi dan $45,1 \%$ responden memiliki motivasi sedang dalam pengobatan hipertensi.

Pada penelitian ini didapatkan hasil riwayat pendidikan responden paling banyak adalah SD yaitu 29,8\%. Menurut Notoatmojo (2007) Pengetahuan merupakan sesuatu hal yang dapat dikatakan bahwa memiliki pengaruh terhadap motivasi seseorang, pengetahuan diperlukan sebagai upaya untuk membentuk rasa percaya diri dalam memunculkan sebuah perilaku yang dilakukan sehari-hari, sehingga dapat dikatakan pengetahuan adalah domain yang penting dalam pembentukan motivasi seseorang (Romadhan, 2014). Seseorang akan cenderung menumbuhkan motivasi dan rasa percaya diri untuk melakukan sesuatu ketika mereka mengetahui manfaat yang akan didapatkan (Iversen, 2006). Perbedaan ini memungkinkan dapat dipengaruhi karena seseorang dapat mendapatkan pengetahuan tidak hanya dari bangku sekolah, dan beberapa faktor lain juga dapat mempengaruhi hasil penelitian ini.

Faktor lain yang mempengaruhi adalah gender. Hasil dalam penelitian ini menunjukkan bahwa responden paling banyak adalah perempuan sejumlah $63,1 \%$ yang menunjukkan bahwa perempuan memiliki motivasi yang lebih tinggi. Penelitian yang dilakukan oleh Edwards (2016) yang menyatakan bahwa perempuan cenderung memiliki motivasi lebih tinggi dalam hal manajemen stres, perilaku kesehatan yang positif, kontrol berat badan, penampilan, dan kegesitan. Karakeristik 
perbedaan gender memiliki keterkaitan dengan motivasi seseorang. Perempuan cenderung dikaitkan dengan pekerjaan yang banyak seperti halnya bekerja penuh waktu, mengurus keluarga, bersosialisasi, kurang aktif dalam melakukan aktifitas fisik (olahraga) membuat mereka lebih rentan terhadap penyakit kronis, sehingga wanita dilaporkan memiliki motivasi lebih tinggi dalam melakukan perilaku kesehatan untuk menjaga badan tetap dalam kondisi sehat (Dawson, 2007)..

Faktor lain yang mempengaruhi motivasi seseorang adalah usia. Pada penelitian ini didapatkan hasil bahwa reponden rata-rata memiliki usia 59,61 tahun. Seseorang yang memiliki usia lebih tua cenderung berhenti merokok, memperhatikan diet, serta melakukan perilaku yang lebih sehat lainnya umumnya memiliki motivasi yang tinggi untuk menjaga kesehatan diri (National Research Council, 2006). Hal ini menujukkan bahwa mereka yang memiliki usia lebih tua menunjukkan motivasi yang lebih tinggi.

Peneliti dapat berasumsi bahwa motivasi seseorang dipengaruhi oleh beberapa faktor, selain faktor seperti pengetahuan, isyarat, maupun kesadaran dari setiap individu, faktor seperti karakteristik individu juga menjadi penyebab peningkatan motivasi seseorang dalam melakukan perilaku perawatan diri maupun aktifitas sehari- hari.

Tabel 3. Nilai Rerata Perawatan Diri Pasien Hipertensi ( $n=84)$.

\begin{tabular}{llll}
\hline Variabel & Mean & Median & Min-Max \\
\hline Perawatan diri & 56,43 & 57,00 & $43-70$ \\
\hline
\end{tabular}

Tabel 3 menunjukkan nilai rata-rata perawatan diri pasien hipertensi adalah 56,43 dengan nilai tengah 57.00. Nilai minimum perawatan diri responden adalah 43 sedangkan nilai maksimum perawatan diri responden adalah 70. Perilaku perawatan diri pasien hipertensi di Poli Klinik Rumah Sakit Tingkat III Baladhika Husada Jember pada penelitian ini terdiri dari beberapa indikator diantaranya aktivitas fisik, diet rendah sodium, diet rendah lemak, membatasi konsumsi alkohol, tidak merokok, self monitor tekanan darah, pengambilan obat, kontrol berat badan, pengurangan stres, kunjungan ke dokter. Penelitian ini memiliki hasil yang sama dengan penelitian yang dilakukan oleh Bakhsh dkk. (2017) pada pasien hipertensi di Saudi Arabia didapatkan hasil bahwa sebanyak $74,4 \%$ responden penelitiannya memiliki perawatan diri yang 
sedang. Penelitian lain yang memiliki hasil serupa dilakukan oleh Ademe dkk. (2019) pada pasien hipertensi menunjukkan hasil bahwa sebesar $51 \%$ respondennya memiliki praktik perawatan diri sedang. Perilaku perawatan diri dapat dipengaruhi oleh beberapa faktor diantaranya usia, jenis kelamin, pekerjaan dan lain sebagainya (Fawcett, 2005).

Hasil penelitian ini menunjukkan rata-rata usia responden adalah 59,61 tahun sehingga kemungkinan perawatan diri seseorang meningkat seiring dengan bertambahnya usia dikarenakan rasa takut yang muncul akibat kerentanan kesehatan yang dialami seiring dengan bertambahnya usia. Penelitian lain tentang perawatan diri hipertensi dilakukan oleh Douglas (2015) menunjukkan hasil bahwa usia memiliki hubungan signifikan dengan perawatan diri hipertensi dengan arah hubungan positif dimana semakin tinggi usia semakin tinggi pula perawatan diri hipertensi seseorang. Status kesehatan seseorang akan menurun seiring dengan bertambahnya usia, orang paruh baya ataupun lansia akan semakin rentang dengan adanya penyakit. Bahkan menjadi prioritas utama dalam kehidupan (Upoyo, 2018). Seseorang akan merasa takut jika kesehatan mereka semakin buruk seiring dengan bertambahnya usia (Deeks dkk., 2009)
Jenis kelamin merupakan faktor yang dapat mempengaruhi perawatan diri seseorang. Responden penelitian ini menunjukkan hasil bahwa sebanyak $63,1 \%$ adalah perempuan sehingga kemungkinan perempuan memilki perawatan diri yang lebih baik dikarenakan perempuan memegang peranan penting atau bertindak sebagai manajer dalam keluarga. Penelitian yang dilakukan oleh $\mathrm{Hu}$ dkk. (2013) tentang perawatan diri pasien hipertensi didapatkan hasil bahwa sebesar $54 \%$ responden perempuan memiliki perawatan diri yang lebih baik seperti melakukan kepatuhan pengobatan, pengukuran tekanan darah, diet rendah garam, latihan fisik, tidak merokok, dan pembatasan alkohol. Wanita lebih mungkin menghadiri hal semacam skrining kesehatan atau perilaku kesehatan lain. Seringkali wanita menjadi manajer kesehatan keluarga, mendorong pasangan dan anggota keluarga lain untuk menghadiri pemeriksaan kesehatan atau lainnya. (Deesks dkk., 2009).

Faktor lain yang dapat mempengaruhi perawatan diri seseorang adalah status pendidikan. Pada penelitian ini didapatkan hasil bahwa responden dengan riwayat pendidikan SD memiliki nilai rerata paling tinggi yaitu sebesar 29,8\% . Pada penelitian yang dilakukan oleh Gebremichael dkk. (2019) didapatkan hasil bahwa terdapat hubungan yang signifikan antara status pendidikan dengan perilaku perawatan diri 
seseorang dengan $p$ value $=0,001$ dengan arah hubungan positif, dimana semakin tinggi pendidikan seseorang semakin tinggi juga perawatan diri yang dilakukan. Semakin tinggi pendidikan akan membuat seseorang memiliki informasi yang cukup untuk melakukan perawatan diri yang baik (Erceg, 2013). Penerimaan informasi kesehatan dan kesadaran akan pentingnya hal tersebut cenderung lebih didapatkan oleh mereka yang memiliki pendidikan yang lebih tinggi (Los Angeles County Department of Public Health, 2013).

Faktor lain yang dapat mempengaruhi perilaku perawatan diri seseorang adalah pekerjaan, Pada penelitian ini didapatkan hasil bahwa responden yang bekerja sebagai PNS sebanyak 5 orang, dan wiraswasta 13 orang hal ini menunjukkan bahwa seseorang yang memiliki penghasilan memiliki perilaku perawatan diri yang lebih baik. Seseorang yang memiliki pekerjaan akan memiliki penghasilan dalam hidupnya. Pada penelitian yang dilakukan oleh Campble dkk. (2014) tentang pengaruh penghasil terhadap perilaku kesehatan seseorang menunjukkan hasil bahwa mereka yang memiliki penghasilan lebih tinggi cenderung mematuhi dalam hal perilaku kesehatan seperti tidak merokok, kontrol tekanan darah maupun kontrol glukosa. Penelitian dengan hasil serupa dilakukan oleh Laksonen dkk. (2003) yang menunjukkan hasil bahwa baik laki-laki maupun perempuan dengan penghasilan lebih rendah memiliki perilaku yang kurang baik seperti halnya kurang makan sayur, kurang dalam kontrol berat badan serta merokok. Dalam hal ini peneliti memiliki asumsi bahwa perawatan diri seseorang erat kaitannya dipengaruhi oleh beberapa faktor diantaranya self care deficit, self care agency, dan basic condition factor dalam hal ini yang dimaksud adalah karakteristik responden seperti halnya jenis kelamin, pekerjaan, maupun status pendidikan.

Tabel 4 Analisis Hubungan Motivasi dengan Perawatan Diri Pasien Hipertensi (n=84)

\begin{tabular}{lll}
\hline Variabel & \multicolumn{2}{l}{ Perawatan Diri } \\
\hline \multirow{2}{*}{ Motivasi } & $\mathrm{r}$ & 0,444 \\
\cline { 2 - 3 } & P value & 0,000 \\
\hline
\end{tabular}

Berdasarkan hasil uji statistik menggunakan spearmen rank didapatkan hasil bahwa $p$ value $=0,000$ yang berarti Ha gagal ditolak sehingga menunjukkan bahwa ada hubungan antara motivasi dengan perawatan diri pasien hipertensi. Korelasi antara keduanya 
memiliki arah hubungan positif dimana apabila semakin tinggi motivasi maka semakin tinggi pula perawatan diri seseorang, dengan nilai $r$ correlation 0,444 yang berarti bahwa kekuatan hubungan cukup kuat. Hasil penelitian ini sejalan dengan penelitian yang dilakukan oleh Peters (2010) yang dilakukan pada 306 pasien di Amerika serikat menujukkan hasil bahwa motivasi pasien mempengaruhi perilaku seseorang dalam melakukan perilaku kesehatan dalam mengontrol tekanan darah. Hasil penelitian ini juga didukung oleh penelitian yang dilakukan oleh Xu (2009) yang menyatakan bahwa meningkatnya motivasi seseorang sejalan dengan meningkatnya kemungkinan dalam perilaku kesehatan. Penelitian yang juga mendukung hasil penelitian ini dilakukan oleh Jung dkk. (2016) tentang hubungan motivasi dengan perawatan diri pasien low back pain didapatkan hasil bahwa ada hubungan yang signifikan antara motivasi dengan perawatan diri pasien dengan nilai $p$ value $=0,01$.

Perawatan diri seseorang dapat dipengaruhi oleh beberapa faktor diantaranya health literacy, self efficacy, motivasi, dan dukungan keluarga (Sabil, 2019). Motivasi seseorang dikaitkan dengan komitmen untuk merubah dan mengembangkan kepercayaan diri dalam merubah perilaku. Motivasi kesehatan merupakan salah satu penentu terpenting dalam melakukan perilaku kesehatan (Xu, 2009). Selain itu motivasi juga menjadi prediktor kuat dalam perilaku seseorang dalam melakukan perawatan diri, melakukan aktivitas fisik, diet, serta mengontrol berat badan (Han dkk., 2014). ). Motivasi merupakan sesuatu yang mendorong atau bertindak sebagai pendorong bagi seseorang untuk melakukan tingkah laku untuk mencapai tujuan (Saam, 2012 dalam Dani dkk., 2015). Motivasi sendiri dapat meningkatkan perilaku seseorang dalam melakukan tindakan perawatan diri (Muna dan Soleha, 2014).

Motivasi dapat mempengaruhi perilaku seseorang atas fungsinya sebagai sumber daya emosional, sehingga orang dapat melakukan tindakan sesuai dengan tujuan yang telah ditetapkan (Choi dkk., 2014). Motivasi dapat bersifat intrinsik dan ekstrinsik dan keduanya memainkan peran dalam mempengaruhi perilaku perawatan diri. Sebagai contoh dalam perawatan diri terkait perilaku berolahraga, motivasi intrinsik dan ekstrinsik memegang peranan penting tetapi motivasi intrinsik lebih sering dinyatakan sebagai motivator pada pasien dengan gagal jantung daripada motivasi ekstrinsik. Ketika pasien melihat manfaat yang jelas, mereka mungkin lebih termotivasi. Manfaat awal untuk melakukan perawatan diri ditemukan termasuk mengurangi gejala dan meningkatkan 
kualitas hidup. Pasien dapat termotivasi untuk perawatan diri dengan nilai-nilai yang terkait dengan perasaan pribadi (pengarahan diri sendiri, kesenangan, dan menjadi sehat) atau terkait dengan keadaan hidup mereka (mempertahankan gaya hidup sehat dan keseimbangan keuangan). Peningkatan motivasi seseorang akan memperbaiki perilaku hidupnya. Pasien juga dimotivasi oleh nilai-nilai yang berbasis sosial seperti halnya manfaat yang diterima dari masyarakat diantaranya pengakuan sosial, sosialisasi dan kewajiban sosial (Jarsma dkk., 2017).

Peneliti dalam hal ini memiliki asumsi bahwa perawatan diri seseorang dapat dipengaruhi oleh beberapa faktor seperti halnya faktor karakteristik individu maupun faktor lain seperti halnya self efficacy, health literacy, dukungan keluarga dan motivasi. Motivasi dalam hal ini erat kaitannya dengan perawatan diri seseorang dihubungkan dalam komitmen seseorang untuk melakukan perubahan perilaku kesehatan maupun perilaku perawatan diri pasien.

\section{SIMPULAN}

Berdasarkan penelitian yang telah dilakukan terdapat hubungan antara motivasi dengan perawatan diri pasien hipertensi di Poli Klinik Rumah Sakit Tingkat III Baladhika Husada Jember. Adapun arah hubungan kedua variabel bersifat positif dengan keeratan hubungan dalam rencang cukup kuat. Perawat berperan penting dalam Menggali pengaruh motivasi untuk perawatan diri pasien serta meningkatkan sikap dan keyakinan pasien untuk mewujudkan perubahan sikap dalam meingkatkan kesehatan agar mampu meningkatkan perawatan diri terhadap penyakitnya. Metode Cognitif Behavior Theraphy (CBT) dengan metode berbasis predisposing reinforcing, and enabling constructs in educational diagnosis and evaluation (PRECEDE ) dapat digunakan sekaligus membuat rencana tindakan atau perawatan yang terjadwal dengan melibatkan pasien, ini sesuai dengan teori Health Belief model (HBM) dimana seseorang yang telah mendapatkan inforomasi dan keterampilan terkait dengan penyakitnya akan mempunyai persepsi yang baik pula terhadap penyakitnya dan akan meningkatkan motivasi pasien.

Hasil tersebut dapat digunakan sebagai dasar dalam praktik keperawatan untuk dapat memberikan asuhan ke arah yang lebih komperhensif dengan memperhatikan aspek psikososial pasien khususnya motivasi. Motivasi pasien dirasa perlu untuk digali dan ditingkatkan, hal ini berhubungan dengan peningkatan perawatan diri secara mandiri yang dilakukan seiring dengan 
meningkatnya motivasi, sehingga berdampak terhadap optimalnya asuhan keperawatan yang diberikan kepada masingmasing individu. Adapun rekomendasi bagi penelitian selanjutnya adalah dapat melakukan penelitian tentang faktor yang dapat mempengaruhi perawatan diri hipertensi lainnya diantaranya, self efficacy, dukungan keluarga dan self agency.

\section{UCAPAN TERIMA KASIH}

1. Almamater Program Studi Fakultas Keperawatan Universitas Jember dan seluruh bapak/ ibu dosen yang telah memberikan ilmu dan bimbingan dengan sabar selama ini.

2. Kelompok Riset Holistic in Medica Surgica Nursing, Dosen pembimbing skripsi Murtaqib, S.Kp.,M.Kep, Ns. Kushariyadi, S.Kep.,M.Kep, Ns. Erti Ikhtiarini Dewi, M.kep., Sp.Kep.J, Ns. Enggal Hadi K., S.Kep, M.Kep. yang telah membimbing hingga akhir.

3. Responden penelitian yakni pasien hipertensi di Poli Klinik RS Tingkat III Baladhika Husada Jember yang berkenan menjadi responden penelitian saya sehingga daya dapat menyelesaikan artikel ini.

\section{DAFTAR RUJUKAN}

Ademe, S., F. Aga., \& D, Gela. 2019. Hypertension self -care practice and associated factor emong patient in publick health facilities of Desch
Town, Ethiopia. BMC Health Services Research. 19(51):1-9

Bakhsh, L. A., A. A. Adas, M. A. Murad, R. M. Nourah, S. A. Hanbazazah, A. A. Aljahdali, \& R. J. Alshareef. 2017. Awerness and knowledge on hypertension and its self-care practic among hypertentive patient in Saudi Arabia. Annals of International Medical and Dental Research. 3(5):58-62

Cahyani, Y. E. 2019. Gambaran Perawatan diri Management Penderita Hipertensi Di Puskesmas Grogol Kebupaten Sukoharjo. Universitas Muhammadiyah Surakarta.

Campbel, D. J. T., P. E. Ronksley, B. J. Manns, M. Tonelli, \& C. Sanmartin. 2014. The association of income with health behavior change and disease monitoring among patient with chronic disease. PLOS One. 9(4):1-8

Dani, R., G. T. Utami, \& Bayhakki. 2015. Hubungan motivasi, harapan, dan dukungan petugas kesehatan terhadap kepatuhan paisen gagal ginjal kronik untuk menjalani hemodialisis. JOM. 2(2)

Dasgupta, Aparajita, S. Sembiah, B. Paul, A. Ghosh, B. Biswas, N. Mallick, A Dasgupta, J. C. Med, \& P. Health. 2018. Assessment of self-care practices among hypertensive patients : a clinic based study in rural area of singur, west bengal. International Journal of Community Medicine and Public Health. 5(1):262-267.

Dawson, K. A., M. A. Schnelder, P.C. Fletcher,\& P. J. Bryden. 2007. Examining gender differences in the health behaviour of Canadian University Student. The Journal of The 
Royal Society for The Promotion of Health. 127(1):38-44

Deeks, A., C. Lombard, \& J. Michhelmore. 2009. The effect of gender on healtth related behaviors. BMC Public Health. 9:2-13

Douglas, B. M., \& E. P. Howard. 2015. Predictor of self management behaviors in older adults with hypertension. Advances in Preventive Medicine. 2015(6):1-6

Edwards, E. S., \& S. C. Sackett. 2016. Psychosocial variable related to why women are less active than men and related health implication. Clinical Medicine Insight Women Health. 16(9):45-47

Erceg, M., A. I. Uhernik, J. kern, \& S. Vuletic. 2013. Is there any association between blood pressure and education level? the cohort study. Coll Antropol. $1: 125-129$

Fahkurnia, W. 2017. Gambaran Perawatan diri Pada Penderita Hipertensi Di Wilayah Kerja Puskesmas Gatak Kabupaten Sukoharjo. Universitas Muhammadiyah Surakarta.

Fitriana, Y., \& R. O. Harysko. 2014. Hubungan karakteristik dan motivasi pasien hipertensi terhadap kepatuhan dalam menjalani pengobatan di puskesmas Talang Kabupaten Solok Tahun 2014.

Gebremichael. G. B., K. K. Berhe. B. G. Beyene, \& K. B. Gebrekidan. 2019. Self-care practices and associated factors among adult hypertensive patients in Ayder Comprehensive Specialized Hospital, Tigray, Ethiopia, 2018. BMC Res Notes. 2019(12):489
Hu, H., G. Ung, \& T. Arao. 2013. Prevalence of self care behaviors and related factors in a rural hypertension population: a Questionnere Survey. International Journal of Hypertension. 2013(8):1-8

Han, H., H. Lee, M. S. N. Mph, \& Y. Commodore-mensah. 2014. Development and validation of the hypertension self-care profile a practical tool to measure hypertension self-care. Journal of Cardiovascular Nursing. 29(3):11-20.

Indrayanti, Sahar, J., \& Henny, P. (2018). Peningkatan Kemampuan dan Penurunan Tekanan Darah pada Agregate Dewasa Hipertensi Sesudah Mengikuti Intervensi Modifikasi Perilaku dengan Hypnocaring (Molusca) di Curug, Cimanggis, Depok. Jurnal Kesehatan, 5(2013), 110.

Iversen, A.C., \& P. Kraft. 2006. Does socioeconomi status and health consciousness influence how women respond to health related message in media. Health Education Research. 21(5):601-610.

Jaarsma, T., J. Cameron, B. Riegel, \& A. Stromberg. 2017. Factors related to self-care in heart failure patients according to the middle-range theory of self-care of chronic illness: a literature update. Curr Heart Fail Rep. 2017 (14):71-77

Jati, D. N, S. 2012. Hubungan dukungan keluarga terhadap motivasi pasien hipertensi dalam melakukan kunnjungan perawatan di instalasi rawat jalan rumah sakit Islam Surakarta. Skripsi. Surakarta: Fakultas Ilmu Kesehatan Universitas Muhamadiyah Surakarta. 
Jung, M. J., \& Y. Jeong. 2016. Motivation and self-management behavior of the individuals with chronic low back pain. National Association of Orthopaedic Nurses. 00(0):1-10

Kharisna, D., H, Ropi., U, Rahayu. 2017. The Factors that are Related to SelfCare Agency in Patients with Hypertensio. Padjadjaran Noursing Journal. 6(1): 1-17

Laksoonen, M., R. Prattala, \& V. Helasoja. 2003. Income and health behaviors: Evidence From Monitoring Surveys Among Finnish Adults. Journal Epidemial Community Health. 57:711717

Lestari, I. G. \& N. Isnaini. 2018. Pengaruh perawatan diri management terhadap tekanan darah lansia yang mengalami hipertesi. Indonesian Journal for Health Sciences. 02(01):7-18.

Motlagh, S. F. Z., Chaman, R., Sadeghi, E., \& Eslami, A. A. (2016). Self-Care Behaviors and Related Factors in Hypertensive Patients. Iran Red Crescent Med J, (16). https://doi.org/10.5812/ircmj.35805.R esearch

Notoatmojo. 2012 Metodologi Penelitian Kesehatan, Jakarta: PT Rineka Cipta.

Peters, R. M., \& T. N. Templin. 2010. Theory of planned behavior, self-care motivation, and blood pressure selfcare. Res Theory Nurs Pract . 24(3): 172-186

Rohman, M. S., N, Hersunarti, A, A. Soenarta, Suhardjono, A. Mayza, A. A. Lukito, \& A. Kosasih. 2011. Pemahaman dokter indonesia mengenai hipertensi dan permasalahan yang dihadapi pada praktik sehari-hari.
Artikel Penelitian. 61(November):5157.

Romadhan, F. A., \& A. Sudaryanto. 2014. Hubungan antara tingkat penetahuan dengan motivasi melakukan latihan fisik pada klien diabetes melitus di desa Delanggu Kabupaten Klaten. 6675

Sabil, F. A., K. S. Kadar, \& E. L. Sjattar. 2019. Faktor- faktor pendukung perawatan diri management diabetes melitus tipe 2: a literature review. 10:48-57.

Upoyo, A. S., A, Taufik. 2018. The Different of Finger Handheld and Deep Breathing Relaxation Techniques Effect on Reducing Heart Rate and Stress Levels in Primary Hypertension Patients. Padjadjaran Noursing Journal. 7(3) : 266-273

Wulandhani, S. A., S. Nurchayati, \& W. Lestari. 2014. Hubungan dukungan keluarga dengan motivasi lansia hipertensi dalam memeriksakan tekanan darah. JOM. 1(2):1-10 